\title{
A HENGERFELÜLETTEL ÉLEZETT EGYENES FOGÚ METSZŐKERÉK MODELL NUMERIKUS KIÉRTÉKELÉSE
}

\section{NUMERICAL EVALUATION OF THE SHAPER CUTTER WITH CYLINDRICAL RAKE FACE}

\author{
Máté Márton, ${ }^{1}$ Hollanda Dénes ${ }^{2}$ \\ Sapientia Erdélyi Magyar Tudományegyetem, Marosvásárhelyi Kar, Gépészmérnöki Tanszék, \\ Marosvásárhely, Románia \\ ${ }^{1}$ mmate@ms.sapientia.ro \\ ${ }^{2}$ hollanda@ms.sapientia.ro
}

\begin{abstract}
This paper deals with the geometric built-up of a theoretically profile errorless shaper cutter. Its proposed rake face is a cylindrical surface for each tooth. The setting parameters of this are the axis inclination angle and the grinding wheel's radius. The possible domain of the setting parameters is computed from geometrical restrictive conditions. The proposed numerical evaluation consists in the computing of the orthogonal rake angle variation, together with the deviation of the generating pro-file from the perfect involute. The obtained results allow the formulation of some conclusions regarding the influence of the cylinder radius and the axis inclination: the best rake angle distributions are obtained when using increased radius values, while profile deviation becomes minimal when using smaller radii and axis inclination angles.
\end{abstract}

Keywords: shaper cutter, rake face, rake angle, distribution, profile error.

\section{Összefoglalás}

Jelen tanulmány a hengerfelülettel élezett egyenes fogú metszőkerék geometriájának és várható profilpontosságának numerikus vizsgálatát mutatja be. Az elméleti profilhibamentes metszőkerék javasolt homlokfelülete mindegyik fogra külön álló körhengerfelület. Ennek beállítási paraméterei a henger tengelyének dőlésszöge és sugara. A paraméterek lehetséges intervallumának számítása geometriai korlátfeltételek alapján történik. A kapott tartományban az ortogonális konstruktív homlokszög értékeket és az evolvens profiltól való eltérést értékeltük ki. Az eredmények alátámasztják azt a következtetést, miszerint a legmegfelelőbb homlokszögeloszlások a nagy köszörükorong-sugarak esetében, míg az evolvenstől való legkisebb eltérés a kis sugarak és kis értékű tengelydőlésszögek esetében keletkeznek.

Kulcsszavak: metszőkerék, homlokfelület, homlokszög, eloszlás, profilhiba.

\section{A hengerfelülettel élezett egyenes fogú metszőkerék modell áttekintése}

A metszőkerekek elméleti profilhibával rendelkező szerszámok. A profilhiba türéshatáron belül tartására alkalmazott klasszikus megoldás a kis homlokszög- és hátszögértékek használata [1, 2]. A klasszikus egyenes fogú metszőkerék homlokfelülete és fejszalag-hátfelülete egyenes körkúpok, melyek a $\gamma_{V}=5^{\circ}$ és $\alpha_{V}=6^{\circ}$ csúcsgeometriát biztosítják, aminek következtében az oldalhomlokszög az oldalélcsúcsban sem éri el a $2^{\circ}$-os értéket, bármely más pontjában pedig ennél is kisebb. A jelen közleményben javasolt metszőkerék modell előnye abban áll, hogy az oldalgeometria jobb forgácsképződést biztosít, az elméleti profilhiba pedig - az új szerszám esetében - nulla, a kopott szerszám esetében pedig elhanyagolható. 
A hengerfelülettel élezett metszőkereket nem a generáló léc képezi, hanem a generálókerékről származtatjuk. A modell részletes matematikai leírása [3] a következő geometriai elveken alapszik: - a generálókerék a metszőkerék fogszámával megegyező, a szükséges szerszámfejszalag-méret alapján számított lehető legnagyobb profileltolású fogaskerék;

- a homlokfelület $\rho_{p}$ sugarú hengerfelület, melynek tengelye $\gamma_{a}$ szöget zár be a szerszám tengelyére merőleges síkkal;

- a szerszám élei a generáló fogaskerék oldalfelületeinek (evolvens hengerek) és a homlokfelület metszéseként jönnek létre;

- a szerszám oldalfelületei olyan csavarfelületek, melyek menetemelkedését a szabadon választott oldalhátszögértékből számítjuk ki.

A generálókerék felületeit és az ezekre illeszkedő éleket az 1. ábrán szemléltettük.

Megfigyelhető, hogy adott beállítás esetén az él alig emelkedik ki az alapsíkból, vagyis az evolvens síkjából, és ennek ellenére a homlokszög lényegesen nagyobb, mint a klasszikus metszőkerekek esetében.

A szerszám fogoldalait és a homlokfelületet a 2. ábrán szemléltettük. A menetemelkedést $2^{\circ}$-os oldalhátszögértékre számítottuk ki.

Az ábrán két homlokfelületet tüntettünk fel: a ráccsal reprezentált, z-tengely pozitív irányításának megfelelően eltolt felület a metszőkerék végső élezési stádiumának felel meg.

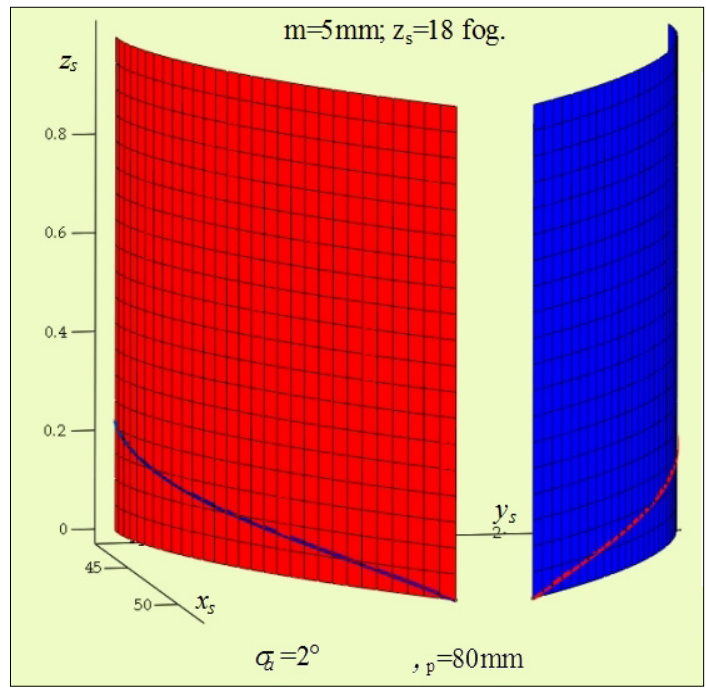

1. ábra. A származtató kerék fogoldalai és a metszökerék oldalélei

\section{A beállítási határok kiszámítása}

Matematikai szempontból kijelenthető, hogy a két független paraméter kétszeres végtelenségnyi homlokfelület-beállítást enged meg; ezek közül ki kell választanunk azokat, amelyek műszaki szempontból lehetségesek. A korlátfeltételek felállításakor két szempontot vettünk figyelembe:

- a hengerfelület és a generálókerék metszésgörbéje a teljes fogmagasságra ki kell hogy terjedjen;

-az oldalhomlokszögnek az élcsúcsban megadott értéket kell felvennie.

Belátható, hogy az első feltétel a körhenger lehetséges legkisebb sugarát adja, míg a második a tengely dőlési szögét határolja le. A számításokat részletesen a [3] közlemény tartalmazza. Az első feltételhez tartozó egyenlőtlenség a következő képletekkel írható fel:

$$
\begin{gathered}
\sqrt{\rho_{p}^{2}-\left(\sqrt{\rho_{p}^{2}-\frac{s_{a}^{2}}{4}}-\Delta H_{c} \sin \gamma_{a}\right)^{2}} \geq y_{C} \\
y_{C}=R_{b} \sin \varepsilon-\left(R_{b} \operatorname{tg} \alpha_{t}+\rho_{f}\right) \cos \varepsilon+\rho_{f} \cos \left(\psi_{1}\right) \\
\rho_{f}=\frac{R_{t}^{2}-R_{f}^{2}}{2\left(R_{f}-\sqrt{R_{t}^{2}-R_{f}^{2}}\right)} \\
\psi_{1}=\operatorname{tg} \alpha_{t}-\eta+\arcsin \frac{R_{b}}{R_{f}+\rho_{f}}
\end{gathered}
$$

$\mathrm{Az}$ (1) képletekben a $t$ index a talpkörre, az $f$ index pedig a lábkörre vonatkozik. A fogprofil

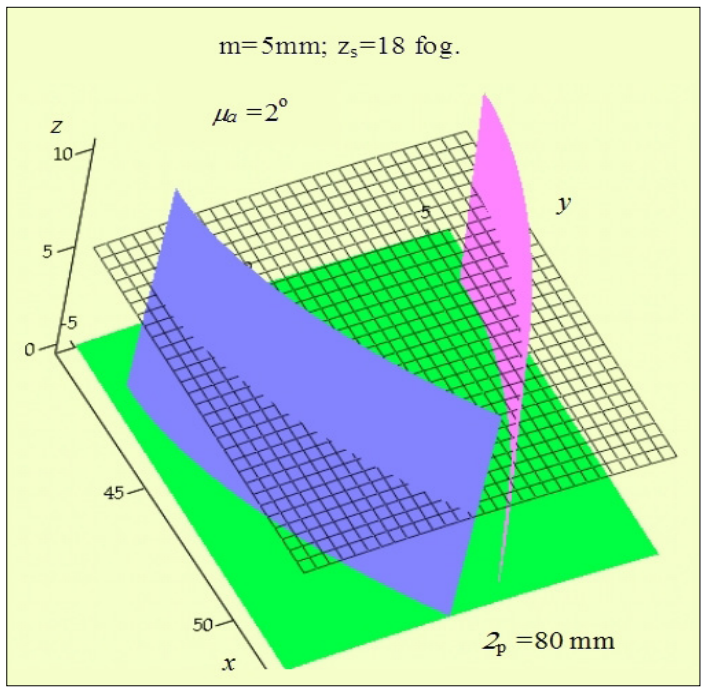

2. ábra. A metszőkerék oldal-hátfelületei és a homlokfelületek 
lábgörbéjét egy $\rho_{f}$ sugarú körívvel közelítjük meg [4], [6].

A második feltétel kapcsolatot teremt a $\rho_{p}$ sugár és a $\gamma_{\mathrm{a}}$ tengelydöntési szög között:

$$
\begin{gathered}
\operatorname{tg} \gamma_{O a}=\operatorname{tg} \gamma_{a} \sin \psi+\frac{s_{a}}{2 \sqrt{\rho_{p}^{2}-\frac{s_{a}^{2}}{4}}} \frac{\cos \psi}{\cos \gamma_{a}} \\
\psi=\operatorname{tg} \alpha_{a}-\eta
\end{gathered}
$$

Az (1) feltételt $m=5 \mathrm{~mm}, Z_{s}=18$ fogú metszőkerékre, $\gamma_{a} \in\left[2^{\circ}, 10^{\circ}\right]$ és $\rho_{p} \in[20,100]$ paraméterértékek között ábrázoltuk. $\mathrm{Az} \mathrm{F}_{1}$ feltételértékeket a 3. ábrán szemléltettük.

A felület és a független változók síkjának metszésgörbéje a határgörbe, amely meghatározza a lehetséges $\left(\gamma_{a}, \rho_{p}\right)$ párok értékeinek mértani helyét. Belátható, hogy ez a határgörbe által definiált azon félsík, mely nem tartalmazza az origót.

A határgörbe pontjait numerikusan számítottuk ki. E célból a $\gamma_{a}$ szög intervallumán $\mathrm{N}=30$ ekvidisztáns értéket vettünk fel, melyekhez a lehetséges elméleti legkisebb sugárértéket társítjuk, majd pedig ezt az értéket addig növeljük, amíg az

$$
\mathrm{F}_{1}\left(\gamma_{a}, \rho_{\text {pmin }}\right) \mathrm{F}_{1}\left(\gamma_{a}, \rho_{\text {pmin }}+\delta_{\rho}\right)<0
$$

feltétel teljesül. Ezután a húrmódszer segítségével, $10^{-4}$ pontossággal számítjuk ki a határsugárértéket. A kapott határgörbét a 4. ábrán szemléltettük.

A második feltételből megkapjuk a lehetséges $\left(\gamma_{a}, \rho_{p}\right)$ párokat, amelyekre teljesül egy adott ortogonális csúcshomlokszögérték.

A további számítások megkönnyítése végett a határgörbe $\mathrm{N}=30$ pontjára felírjuk a

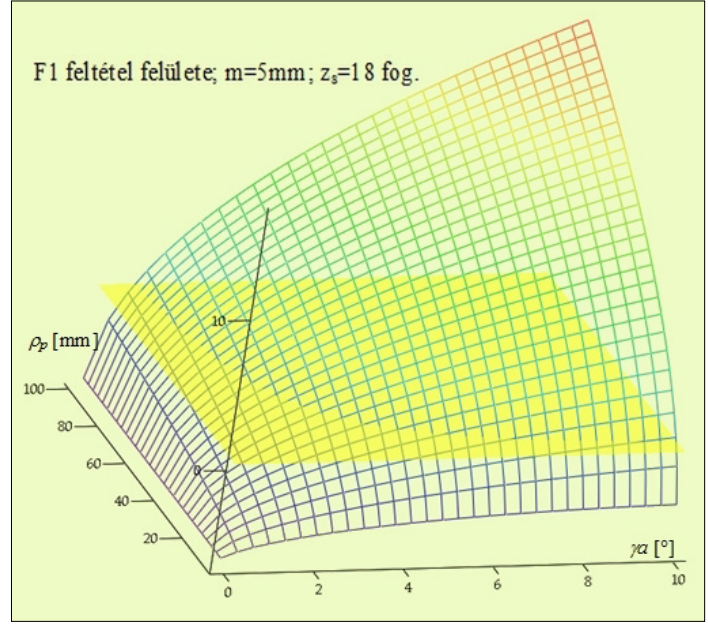

3. ábra. Az F1 feltételhez csatolt felület

$$
\begin{aligned}
\gamma_{a}\left(\rho_{p}\right) & =\operatorname{Sp}_{1}\left(\rho_{p}\right) \\
\rho_{p}\left(\gamma_{a}\right) & =\operatorname{Sp}_{2}\left(\gamma_{a}\right)
\end{aligned}
$$

spline függvényeket. A szerszám felépítésében alkalmazható ortogonális csúcshomlokszögértékeket a $\gamma_{O a} \in\left[3^{\circ}, 9^{\circ}\right]$ értéktartományban tekintjük, és a tartományt szintén 30 pontra osztottuk fel, ezáltal közel 12 szögpercnyi távolságú egyenletes beosztást nyerünk.

Adott $\gamma_{O a}$ értékre megvizsgáljuk a lehetséges értékeket. A (2) feltételben szereplő gyök alatti kifejezés mindig pozitív kell hogy legyen. Ez akkor teljesül, ha

$$
\operatorname{tg} \gamma_{O a}-\operatorname{tg} \gamma_{a} \sin \psi>0
$$

Innen számítjuk ki a tengely dőlésszögének a legnagyobb értékét. A legkisebb érték értelemszerűen a műszaki szempontból elfogadható érték. $\mathrm{Az}$ adott $\gamma_{O a}$ értékre felállított intervallumban, $\mathrm{N}=30$ egyenlő elosztású pontban kiszámítjuk a (2) feltételből a megfelelő $\left(\gamma_{a}, \rho_{p}\right)$ értékeket. A kapott szintgörbéket és a határgörbét az 5 . ábrán tüntettük fel.

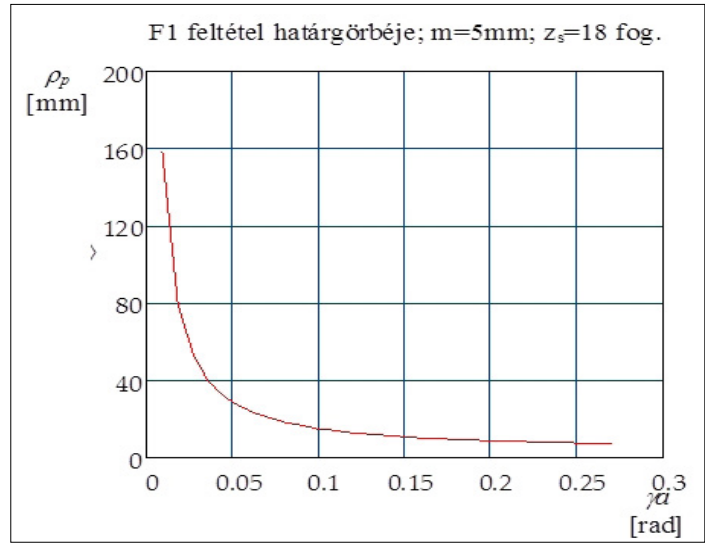

4. ábra. Az $F_{1}$ feltételből származó határgörbe

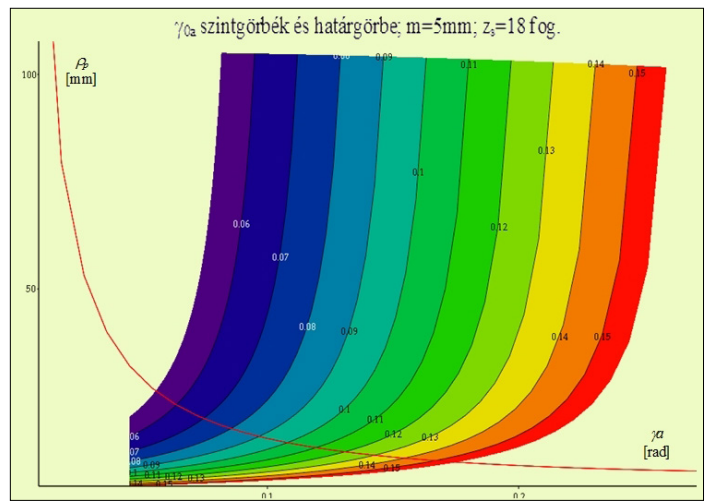

5. ábra. $A \gamma_{O a}=$ konst. szintgörbék és a korlátfeltétel 


\section{Az oldalhomlokszög változása}

Az oldalfelület, a homlokfelület és az él kifejezéseinek ismeretében a homlokszöget a konstruktív élszögrendszer bázisvektoraival, valamint az él érintő- és a homlokfelület normális vektorával írjuk fel [5], [7], [8]:

A konstruktív ortogonális homlokszög számítását a

$$
\sin \gamma_{O}=\frac{\mathbf{n}_{\gamma} \cdot \mathbf{j}}{\left|\mathbf{n}_{\gamma} \times \mathbf{i}\right|}
$$

vektorképlettel számoljuk ki [7], [8]. A kifejezés felépítésében szereplő vektorokat a 6 . ábrán tüntettük fel. A konstruktív koordináta-rendszert az él tetszőleges $M$ pontjában vettük fel, ahol $\mathbf{k}$ az alapsík, j az érintősík, i pedig az ortogonális sík normál-egységvektorai, $\boldsymbol{\tau}$ az él érintővektora, $\mathbf{n}_{\gamma}$ pedig a homlokfelület normálvektora. Az említett vektorok számításához szükség van a származtatófelület, az él és a homlokfelület egyenleteire. Ezek részletes számítása a [3] közleményben található. A vektorokat a metszőkerék fogára tájolt koordináta-rendszerben írjuk fel. A konstruktív koordináta-rendszer bázisvektorait a következő módon számítjuk:

$$
\begin{aligned}
\mathbf{k} & =\left(\begin{array}{lll}
0 & 0 & -1
\end{array}\right)^{T} \\
\mathbf{j} & =\frac{\mathbf{k} \times \boldsymbol{\tau}}{|\mathbf{k} \times \boldsymbol{\tau}|} \\
\mathbf{i} & =\mathbf{j} \times \mathbf{k} \\
\boldsymbol{\tau} & =\left(\begin{array}{lll}
\frac{\partial F_{h}}{\partial x} & \frac{\partial F_{h}}{\partial y} & \frac{\partial F_{h}}{\partial z}
\end{array}\right)^{T}
\end{aligned}
$$

A (10) képletben $F_{h}$-val jelöltük a hengerfelület implicit egyenletét.

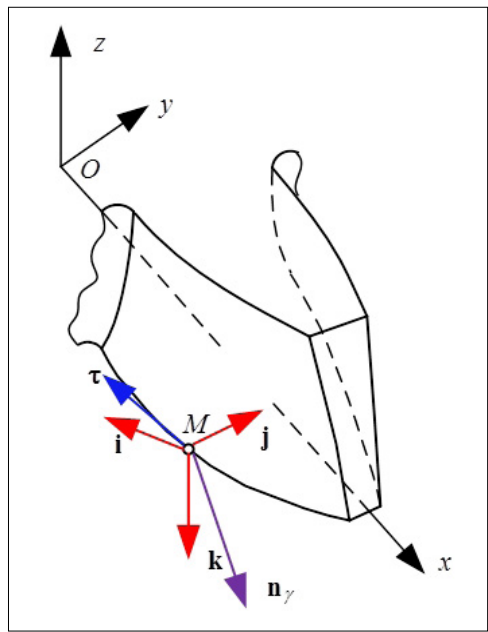

6. ábra. Az oldalhomlokszög számítási képlete
A továbbiakban különböző tengelydőlésszög- és köszörükorongsugár-értékekre vizsgáltuk az ortogonális homlokszögeloszlást.

Az értelmezési tartományon belül a $\gamma_{\mathrm{a}} \in\left[2^{\circ}, 5^{\circ}\right]$ és a $\rho_{\mathrm{p}} \in\left[\rho_{p m i n}, 100\right]$ intervallumokra definiált $\left\{2^{\circ} ; 3^{\circ} ; 4^{\circ} ; 5^{\circ}\right\} \times\left\{\rho_{\text {pmin }} ; 40 ; 60 ; 80 ; 100\right\}$ párokra végeztük el az értékek elemzését. A $\rho_{p \min }$ érték a $\gamma_{\mathrm{a}}$ dőlésszög értékével fordítottan arányos.

A 7. ábra az ortogonális homlokszög-eloszlásokat ábrázolja. A felületek alakja és kölcsönös helyzete az eloszlás következő sajátosságaira enged következtetni:

- az oldalhomlokszög variációs intervalluma annál jobban tolódik el a számtengelyen jobbra, minél kisebb a köszörükorong sugara;

- a variációs intervallum annál nagyobb, minél kisebb a köszörükorong sugara;

- a vizsgált szög eloszlása az él mentén parabolikus.

Az él menti értékeloszlásokat részleteiben a 8., 9., 10. és 11. ábrákon szemléltettük.

A következőkben az eloszlásokat statisztikai szempontok szerint is megvizsgáljuk. A várható értékek eloszlását a 12. ábra tartalmazza.

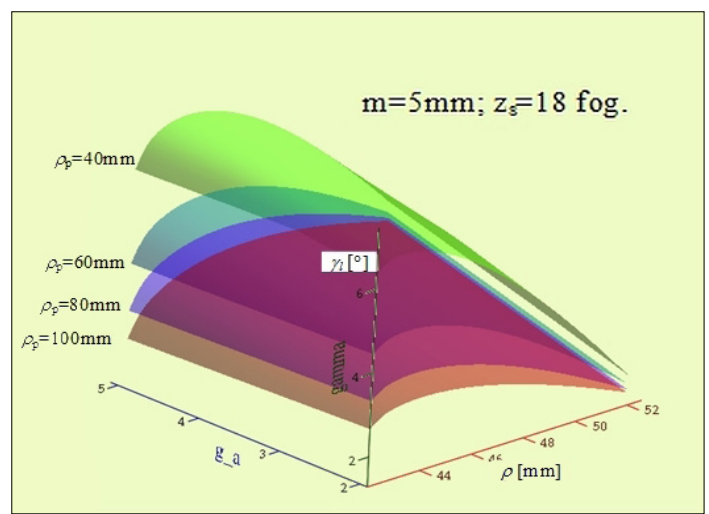

7. ábra. Az ortogonális homlokszögeloszlások az él mentén

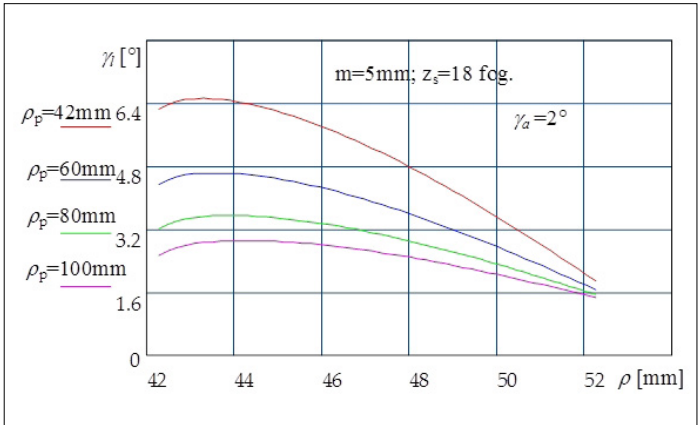

8. ábra. A homlokszögeloszlás $2^{\circ}$-os tengelydőlésszögre 


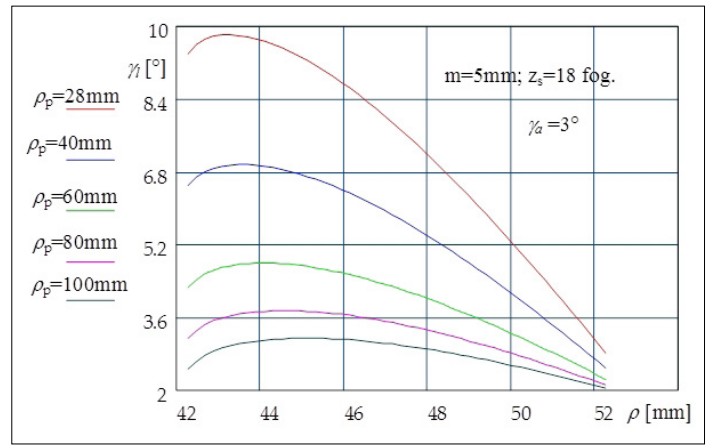

9. ábra. A homlokszögeloszlás $3^{\circ}$-os tengelydőlésszögre

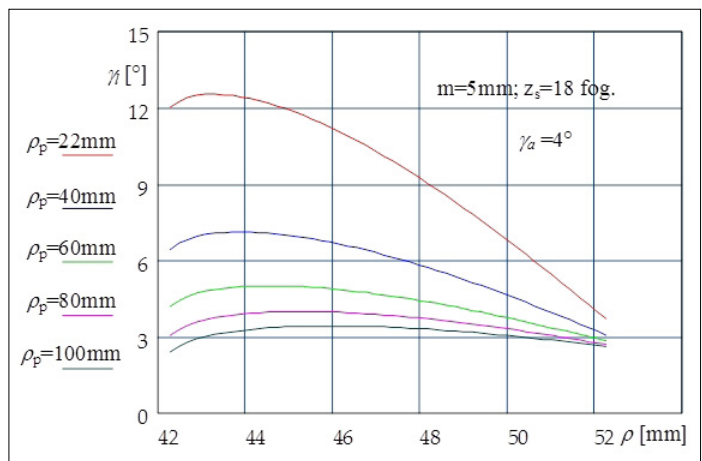

10. ábra. A homlokszögeloszlás $4^{\circ}$-os tengelydölésszögre

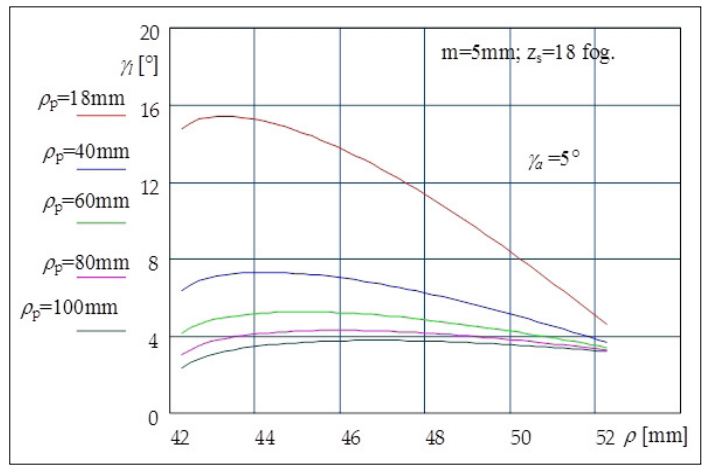

11. ábra. A homlokszögeloszlás $5^{\circ}$-os tengelydőlésszögre

Amint az előzőekben is említettük, a lehetséges legkisebb köszörűkorongsugár-értékek a tengely dőlésszögének függvényei. Azokban a pontokban, ahol a legkisebb sugárérték nem alkalmazható, a várható értéket nullának vettük. A nem nulla értékek alakulása azt mutatja, hogy a várható érték növekedik a tengely dőlési szögével és csökken a köszörükorong sugarával.

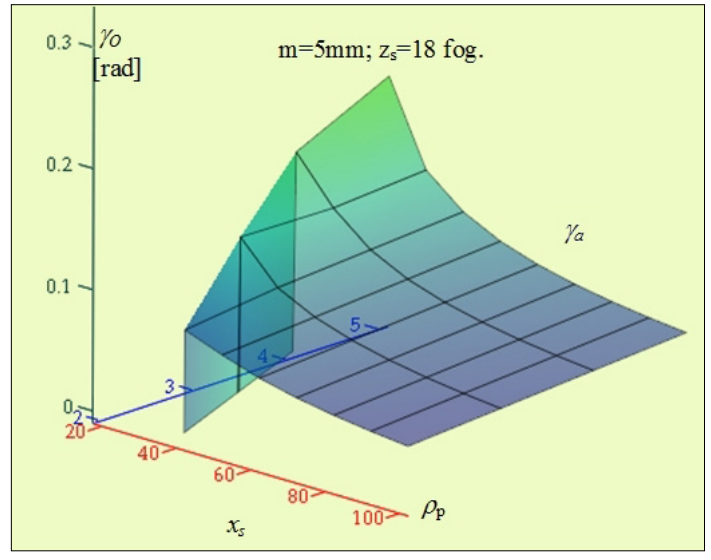

12. ábra. A homlokszög várható értékeinek eloszlása

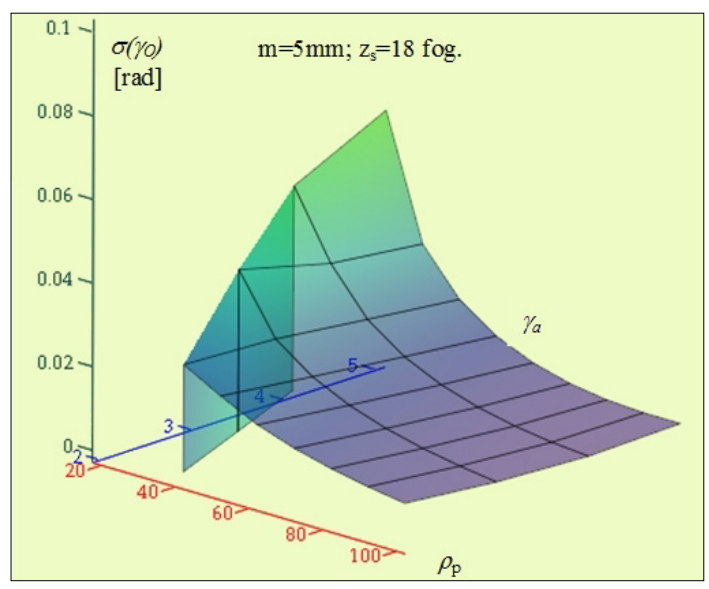

13. ábra. A homlokszögeloszlás szórástérképe

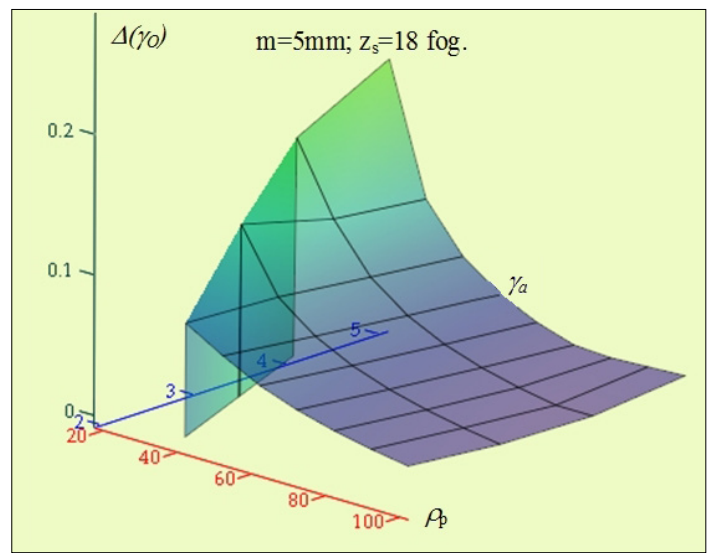

14. ábra. A variációs intervallumok szélességének eloszlása

A szórások eloszlása a 13. ábrán látható. Megfigyelhető, hogy a szórások értékeloszlása ugyanazt a törvényt követi, mint a várható értékek eloszlása. Így a nagyobb várható érték nagyobb 
szórást is eredményez. A szórástérképpel ekvivalens információt nyújt a variációs intervallumok szélességének eloszlása, amit a 14. ábrán szemléltettünk.

Az intervallumszélesség válaszfelületén észre lehet venni, hogy a $\gamma_{a} \in\left(4^{\circ}, 6^{\circ}\right)$ és $\rho_{p} \in(80,100)$ intervallumokkal kijelölt értelmezési tartományban lokális minimumot észlelünk. Egyébként a variációs intervallum szélessége a tengely dőlési szögével növekedik, míg a hengerfelület sugarával csökken.

\section{A fogprofil}

A metszőkerekek esetében két fogprofilt definiálunk: a szerszámprofilt és a származtató profilt. A szerszámprofil az oldal-homlokfelületeknek a szerszám tengelyére merőleges síkkal való metszése során jön létre, míg a szerszám származtató profilja alatt a szerszám oldalélei által a főmozgás során leírt generáló fog profilját értjük. A szerszám technológiai burkolása léc-kerék kapcsolódási elv alapján történik. Ennek különböző leírásait a [6], [9], [10], [11] közleményekben részletesen megtalálhatjuk. Amennyiben a szerszámprofil az evolvens profiltól megengedhetetlen mértékben tér el, a fogoldalakat nem lehet egyenes profilú köszörütárcsával köszörülni, ennélfogva a metszőkeréknek a fogmagassága is változó kell hogy legyen. Ha viszont a szerszámprofil eltérése az evolvenstől a gyártási pontosság alatt van, akkor el lehet képzelni a köszörülést a Maag-

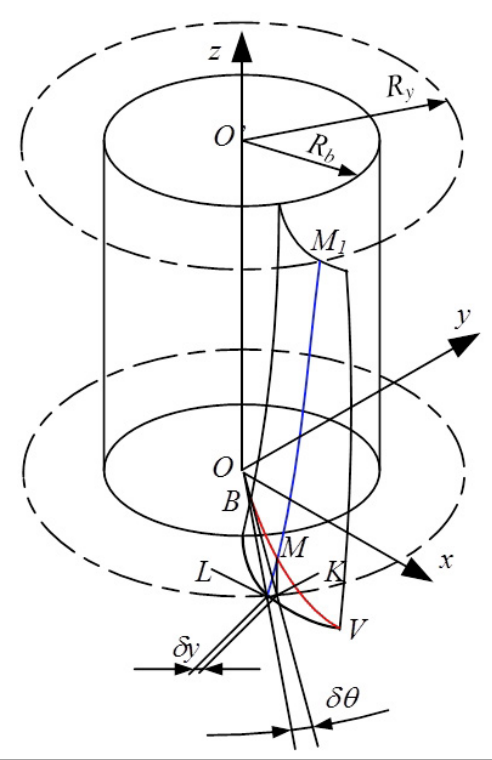

15. ábra. A szerszámprofil kiszámítása vagy a Niles-féle elven, és gyártható az állandó fogmagasságú metszőkerék.

A szerszámprofil előállítását az él parametrikus koordináta-függvényeinek és az oldal-hátfelület csavarparaméterének ismeretében számítjuk ki, a 15. ábra alapján.

Tekintsük az új szerszám élének parametrikus egyenleteit az evolvens henger és a henger-homlokfelület metszéseként:

$$
\begin{aligned}
& \left\{\begin{array}{c}
x(\varphi)=R_{b}(\cos (\varphi-\eta)+\varphi \sin (\varphi-\eta)) \\
y(\varphi)=j R_{b}(\sin (\varphi-\eta)-\varphi \cos (\varphi-\eta)) \\
z(\varphi)=-x(\varphi) \operatorname{tg} \gamma_{a}+\frac{-E+\sqrt{\rho_{p}^{2}-y^{2}(\varphi)}}{\cos \gamma_{a}}
\end{array}\right. \\
& E=\sqrt{\rho_{p}^{2}-\frac{s_{a}^{2}}{4}}-R_{a} \cos \eta_{a} \sin \gamma_{a}
\end{aligned}
$$

Az $M$ élpont sugara, adott $\varphi_{y}$,

$$
\begin{gathered}
0<\varphi_{y}<\sqrt{\frac{R_{a}^{2}}{R_{b}^{2}}-1} \text { paraméter értékre, } \\
R_{y}=R_{b} \sqrt{1+\varphi_{y}^{2}}
\end{gathered}
$$

A vizsgált élpont ugyanakkor az $M M_{1}$ csavarvonalszakaszon is illeszkedik. Az $M$ élpontot a $z=0$ alapsíkra a csavarvonal mentén vetítjük, így a vizsgált pont az $L$ szerszámprofilpontot képezi le. Amennyiben az $M$ pontot a $z$ tengellyel párhuzamosan vetítjük, a $K$ pontot képezi le, ami a metszőkerék származtató profiljának, vagyis - új metszőkerék esetében - a tökéletes evolvensnek pontja. A profileltérést az $R_{y}$ sugarú körön, a $K L$ körív hosszával mérjük. Ismervén a hátfelület csavarparaméterét, $p=R_{b} / \operatorname{tg} \alpha_{l}$, a $K L$ ívet a következőképpen számítjuk ki:

$$
K L \equiv \delta_{y}=\frac{z\left(\varphi_{y}\right)}{p} R_{y}
$$

A (14) összefüggésből észrevehető, hogy minél nagyobbak a $z$-koordináták értékei, a szerszámprofil annál jobban eltér az evolvenstől.

Az előbbiekben kijelölt kísérleti beállításokban kiszámítottuk a $z$-koordináták eloszlását is (16. ábra).

Észre lehet venni, hogy kis dőlésszögekre és kis hengersugárértékekre a $z$-koordináták $0,2 \mathrm{~mm}$ alatti értékűek. Az eloszlást a 17. ábrán tüntettük fel. A dőlésszög értéke $\gamma_{a}=2^{\circ}$.

A négy eltérésgörbe alakjáról és helyezkedéséből észre lehet venni a következőket: 
- a köszörűkorong sugarának növelésével az eltérés növekedik;

- az eltérés csúcsban mindig nulla, hiszen az élcsúcs a $z=0$ síkban található;

- a legnagyobb eltérés értéke $9 \mu \mathrm{m}$, ami nem megengedhető;

- a legkisebb hengersugár esetében a hiba megközelítőleg $4 \mu \mathrm{m}$, ami szerintünk belefér a türéshatárba.

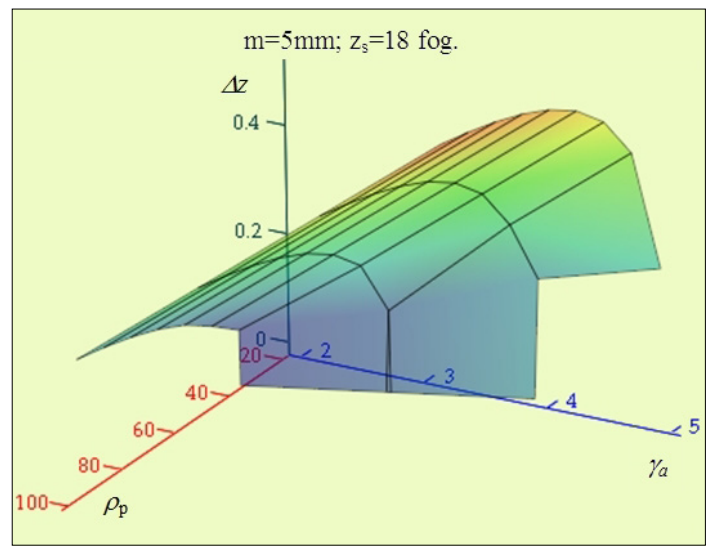

16. ábra. A z-koordináták eloszlása

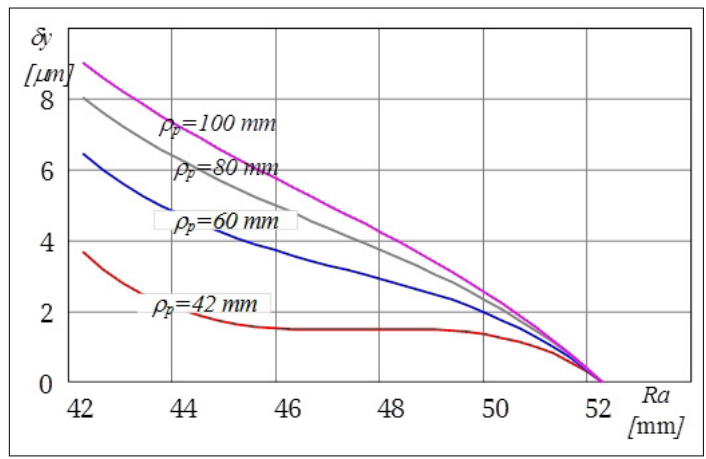

17. ábra. Az eltérésgörbék

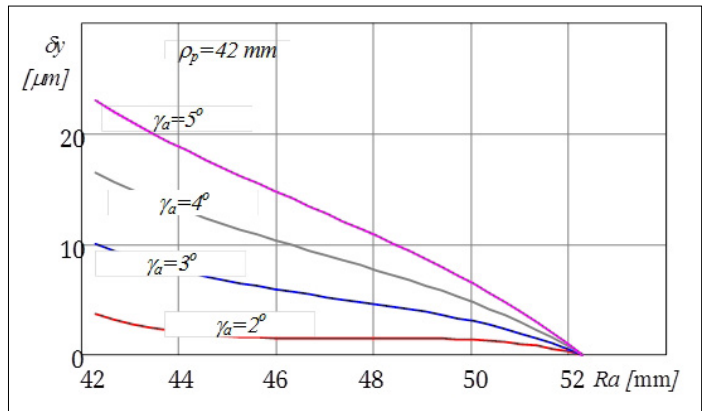

18. ábra. Az eltérés változása a tengely döntési szögével
Ha a hengerfelület sugarát állandó értéken tartjuk, $\rho_{p}=42 \mathrm{~mm}$, és a tengelydőlésszöget változtatjuk, kimutatható az eltérés növekedése a szöggel (18. ábra).

\section{Következtetések}

A fogankénti hengerfelület alkalmazása a közös kúpfelület helyett homlokfelületként számos előnnyel jár. Ezek között a legfontosabb az oldalhomlokszög beállításának lehetősége.

Be kell azonban ismerni, hogy a homlokszögváltozás az él mentén nem állítható be tetszés szerint: minél kisebb a hengerfelület sugara, annál nagyobb a változás. Így a kis dőlésszögeket és a nagy sugarakat kell előnyben részesíteni.

Másrészt, a 18. és a 17. ábrák összevetésével az látszik, hogy kis sugarak és kis dőlésszögek esetében a szerszámot - elfogadható hibával - klasszikus egyenes profilú köszörütárcsával lehet megmunkálni. Ez esetben a szerszám fogmagassága a szerszám tengelye mentén állandó.

Amennyiben az eltérést elfogadhatatlannak tartjuk, a hátfelületek megmunkálása görbe profilú tárcsával lehetséges.

\section{Köszönetnyilvánítás}

A kutatás a Magyar Tudományos Akadémia támogatásával, Domus-ösztöndíj segítségével valósult meg.

\section{Szakirodalmi hivatkozások}

[1] Radzewich S. P.: Gear Cutting Tools. CRC Press, NY, 2010.

[2] Máté M.: Hengeres fogaskerekek gyártószerszámai. Erdélyi Múzeum-Egyesület, 2016.

[3] Máté M., Hollanda D., Forgó, Z., et.al.: Synthesis of a Profile Errorless Involute Shaper Cutter with Cylindrical Rake Face. CINTI-MACRO 2019, Konferenciakötet, megjelenés alatt.

[4] Chung-Biau Tsay Wen, Yao Liu Yi-Cheng Chen: Spur gear generation by shaper cutters. Journal of Materials Processing Technology, 104/3. (2000) 271-279.

[5] Máté M., Kántor A., Laczkó-Benedek B.: Metszőkerékkel lefejtett fogaskerekek profilpontosságának vizsgálata. Müszaki Tudományos Közlemények, 7. (2017) 279-282.

https://doi.org/ 10.33895/mtk-2017.07. 62

[6] Zhou Yuansheng, WuYuanhang, Wang Liming, Tang Jinyuan, Ouyang Hongwuab: A new closedform calculation of envelope surface for modeling face gears. Mechanism and Machine Theory, 137/ July (2019) 211-226.

[7] Máté M.: A possible modelling of the constructive cutting geometry of the gear hobs. In: Proceedings of the 4-th International Scientific Conference on 
Advances. Mechanical Engineering. Debrecen, Magyarország. 2016.

[8] Máté M., Hollanda D.: A hengeres fogaskerék-lefejtő csigamaró müködő élgeometriájának vizsgálata. In: A XVII. Műszaki Tudományos ülésszak előadásai. Műszaki Tudományos Közlemények 6. (2017) 115-120.

https://doi.org/10.33895/mtk-2017.06.15

[9] Balajti Zs.: Examination and adjustment of the bearing pattern in case of helicoid drives. $8^{\text {th }}$ CIRP Conference on High Performance Cutting, Buda- pest, Hungary, June 25-27. 2018. Procedia CIRP, appearance is in progress

[10] Forgó Z., Kakucs A., Máté M., Tolvaly-Roşca F.: Development of Helical Teethed Involute Gear Meshed with a Multi-Edge Cutting Tool Using a Mixed Gear Teeth Modeling Method. Elsevier Procedia Engineering, 181. (2017) 1-60.

https://doi.org/10.1016/j.proeng.2017.02.421

[11] Dudás I.: The Theory \& Practice of Worm Gear Drives. Kogan Page US, Sterling, USA, ISBN 19039 96619 9, 2004. 